\title{
Performance evaluation of portable knapsack power weeder
}

\author{
B. Devojee, S.S. Meena and A.K. Sharma
}

Received : 16.07.2018; Revised : 27.08.2018; Accepted : 14.09.2018

See end of the Paper for authors' affiliation

Correspondence to :

B. Devojee

Department of Farm Machinery and Power Engineering, College of Technology and Engineering, Udaipur (Rajasthan) India Email : devojibhookya@ gmail.com
-ABSTRACT : India is a vast country having agriculture sector as the backbone of its economy. A weed is essentially any plant which grows where it is unwanted or not required. A weed can be thought of as any plant growing in the wrong place at the wrong time and doing more harm to the farmer income. Several weeders are available which run by tractor or power tiller, these are large in size can not work for low inter row spaced crops. The portable knapsack power weeder is evaluated two different crops such as maize and chilliwith each blade $(2,4$ and 6 blades per flange) combination. During the evaluation field capacity, field efficiency, weeding efficiency, plant damage, fuel consumption, performance index were evaluated. Actual field capacity of weeder for maize and chillicrop with 6 blades was $0.023 \mathrm{ha} / \mathrm{hand} 0.025 \mathrm{ha} / \mathrm{h}$. Field efficiency of weeder for maize and chilli crop was 61.3 per cent and 66. 6. Weeding efficiency for maize and chilli crop was 89.3 per cent and 85.2 per cent. Plant damage for maize and chillicrop was 2.4 per cent and 3.30 per cent.

- KEY WORDS : Knapsack power weeder, Field capacity, Field efficiency, Weeding efficiency, Plant damage, Fuel consumption, Performance index

- HOW TO CITE THIS PAPER : Devojee, B., Meena, S.S. and Sharma, A.K. (2018). Performance evaluation of portable knapsack power weeder. Internat. J. Agric. Engg., 11(2) : 364-368, DOI: 10.15740/ HAS/IJAE/11.2/364-368. Copyright@2018: Hind Agri-Horticultural Society. 